\title{
Membangun Kembali Nilai-Nilai Dasar Keislaman sebagai Resolusi Konflik Ahmadiyah: Diskursus Hak Kebebasan Beragama dan Berkeyakinan
}

\author{
Dedi Putra \\ Pusat Kajian Kebijakan Publik dan Hak Asasi Manusia \\ dediputra1412011092@gmail.com
}

\begin{abstract}
Justice, tolerance, and mutual forgiveness is the fundamental values of Islam. The principle must be understood and imitated and realized in social attitudes. But in fact, the principle of nonviolence and peace in Islam was limited to the principle of not integral to the individual Muslim. This has often resulted in various conflicts in society. This paper focuses existence of Ahmadiyah conflict. Ahmadiyah position as a minority group should get protection from the state. The State must ensure and protect the rights of religious freedom which is owned by Ahmadiyah. So with the protection provided by the state, the new state acts can be said to be in accordance with the constitutional mandate.
\end{abstract}

Keywords: The Principles of Islamic Fundamentalism, Conflict Resolution, Ahmadiyya, The Rights of Freedom of Religion and Belief.

\section{Pendahuluan}

Justice, tolerance, and forgiveness are at the heart of the conceptualization of peace in the Quran and Hadith. ${ }^{1}$ Ketiga hal tersebut merupakan konsepsi perdamaian Islam yang didasarkan oleh Al-Quran dan Hadist. Secara terminologi Islam ialah "keselamatan", "kedamaian" dan "penyerahan diri secara total kepada Allah SWT. Jika Islam dimaknai sebagai agama "perdamaian" maka umat manusia yang mendalami, meresapi sambil menyebarkan agama Islam maka mereka seharusnya termasuk orang-orang yang cinta damai. Kedamaian hati umat Islam, tidak hanya pada mereka yang menyebarkan agama Islam melainkan mereka juga yang berinteraksi di tengah masyarakat harus berada dalam lingkaran perdamaian. Setidak-tidaknya mereka berupaya menciptakan situasi damai dalam kehidupan bermasyarakat.

Doktrin perdamaian sangat esensial dalam Islam karena berakar kuat pada doktrin tauhid yang tak hanya berarti "keesaan Allah " tetapi juga keesaan kemanusiaan, kesatuan penciptaan dan kesatuan eksistensi. ${ }^{2}$ Timur dan Barat adalah milik Allah, tegas Allah dalam firmannya:

"Kepunyaan Allah-lah timur dan barat, maka kemanapun kamu menghadap di situlah wajah Allah. Sesungguhnya Allah Maha Luas (rahmatNya) lagi Maha mengetahui. ${ }^{3}$

Hal ini tergambar dari pendapatnya Sawsan Malla Hussein, bahwa:

\footnotetext{
1 Sawsan Malla Hussein, "The Concept of Peace in Islam", International Journal of English Language, Literature and Humanities, Vol. III, Issue VIII, 2014, p.1.

2 Tita Rostitawati, "Teologi dalam Islam", Jurnal Madani, Vol 4. No 1, 2014, p.1.

3 Q.S, Al-Baqarah: 2: 115
} 
"It is also alleged that Islam prohibits all freedom of religion, spreads its faith by the power of the sword alone, and does not tolerate any criticism of its teachings" 4

Bahwa Islam juga memandang secara umum, dilarang bagi agama apapun yang menyebarkan ajarannya hanya menggunakan kekuatan pedang saja dan ini tentunya tidak dapat ditolerir. ${ }^{5}$

Ketika prinsip-prinsip antikekerasan dan konsep perdamaian dibangkitkan dalam konteks Islam, hal tersebut cenderung tidak berlaku untuk sebagian besar mayoritas umat Islam (they tend to be associated not with the life of the vast majority if muslims). Bahkan prinsip-prinsip antikekerasan dan konsep perdamaian tersebut, tidak berlaku di Indonesia untuk pergerakan Ahmadiyah (Ahmadiyah movement).

Ahmadiyah di Indonesia terbagi menjadi dua kelompok. ${ }^{6}$ Kelompok pertama ialah "Ahmadiyya Muslim Jama' at (atau Ahmadiyah Qadian). Pengikut kelompok ini di Indonesia membentuk organisasi bernama Jemaat Ahmadiyah Indonesia, yang telah berbadan hukum sejak 1953 (SK Menteri Kehakiman RI No. JA 5/23/13 Tgl. 13-3-1953). ${ }^{7}$ Kelompok kedua ialah "Ahmadiyya Anjuman Isha'at-e-Islam Lahore" (atau Ahmadiyah Lahore). Di Indonesia, pengikut kelompok ini membentuk organisasi bernama Gerakan Ahmadiyah Indonesia, yang mendapat Badan Hukum Nomor I x tanggal 30 April 1930. Anggaran Dasar organisasi diumumkan Berita Negara tanggal 28 November 1986 Nomor 95 Lampiran Nomor 35.8

Secara hukum, kedudukan Ahmadiyah di Indonesia adalah legal. Hal ini dikarenakan organisasi tersebut memiliki badan hukum yang disahkan oleh SK Kementerian Kehakiman pada waktu itu. Legalitas badan hukum ini kemudian menjadi sirna ketika Pemerintah Indonesia atas nama, Menteri Agama, Menteri Dalam Negeri, dan Jaksa Agung Indonesia pada tanggal 9 Juni 2008 telah mengeluarkan Surat Keputusan Bersama, yang memerintahkan kepada penganut Ahmadiyah untuk menghentikan kegiatannya yang bertentangan dengan Islam. ${ }^{9}$

Sejak diterbitkannya Surat Keputusan Bersama tersebut banyak rintangan, konflik bahkan benturan fisik yang dihadapi oleh Ahmadiyah. Misalnya tindakan penyegelan Masjid Al-Hidayah di Jalan Raya Muhtar RT 3

4 Sawsan Malla Hussein, Op.cit., p. 2.

5 When the principles of nonviolence and concepts of peace are evoked in the context of Islam, they tend to be associated not with the life of the vast majority of Muslims, but with the practices of a few minority sects such as the Ahmadiyah movement or the Sufi tradition.

6 https://id.wikipedia.org/wiki/Ahmadiyyah

7 http://www.thepersecution.org/world/indonesia/05/jai_pr2108.html.

8 http:/ / www.ahmadiyah.org/index.php?go=tentang.

9 "SKB Ahmadiyah diterbitkan". BBCIndonesia.com. 
RW 7 Kelurahan Sawangan Baru, Kecamatan Sawangan, ${ }^{10}$ kekerasan yang didapatkan oleh kelompok Ahmadiyah (include brokes the mosque) ${ }^{11}$, jemaat Ahmadiyah diusir di Kelurahan Srimenanti, Bangka12, pengusiran jemaat Ahmadiyah secara paksa dan menggunakan kekerasan ${ }^{13}$ bahkan eksekusinya menggunakan Komandan Distrik Militer bangka14. Bahkan Pemerintah Daerah Bangka (Bupati Tarmizi) mengatakan:

"Saya ini ngetop di kalangan Ahmadiyah. Saat menjadi Sekda tahun 2010, saya pernah perintahkan untuk menghancurkan masjid Ahmadiyah. Mereka pasti kenal dengan saya. Jadi bukan baru tahu sekarang saat saya minta mereka pindah."

How could the leader of local governent do it? Apakah Ahmadiyah merupakan musuh bangsa? Lalu bagaimana dengan pernyataan dari "The First Presedent of Indonesian said:

"What everyone wants is to become a citizen of one free state, the United Republic of Indonesia. It is the same with me, with the ulamas [clerics], the youth, the officials, everyone without exception: everyone wants to be citizen of the Republic of Indonesia, everyone, without any minorities or majorities."15

Tindakan Pemerintah Daerah tersebut merupakan bentuk dari marjinalisasi dan stigmatisasi kelompok Ahmadiyah, yang sudah berkembang menjadi tindakan diskriminasi. ${ }^{16}$ That's beliefs are now criminalized and a cause for persecution. ${ }^{17}$

10 Imam Hamdi, “Masjid Disegel, Ahmadiyah Depok Tempuh Jalur Hukum”, diakses dari https://metro.tempo.co/read/news/2017/02/24/083850004/masjid-disegel-ahmadiyah-depoktempuh-jalur-hukum, Pada Tanggal 16 Maret 2017, Pukul 23:44.

11 Addi Mawahibun Idhom, "Menteri Agama Sesalkan Perusakan Masjid Ahmadiyah", diakses dari https://nasional.tempo.co/read/news/2016/05/24/173773523/menteri-agamasesalkan-perusakan-masjid-ahmadiyah, Pada Tanggal 16 Maret 2017, Pukul 23: 50 WIB.

12 Vindry Florentin, "Ahmadiyah Minta Pemerintah Penuhi Hak-Haknya", diakses dari https://nasional.tempo.co/read/news/2016/02/09/078743212/ahmadiyah-minta-pemerintahpenuhi-hak-warga-negaranya, Pada Tanggal 16 Maret 2017, Pukul 23:54 WIB.

13 The Setara Institute for Democracy and Peace recorded 11 cases of violence and intolerance against Ahmadiyah groups in 2014.

14 Vindry Florentin, "Diusir Bupati Bangka, 9 Jemaat Ahmadiyah Masih Bertahan”, diakses dari https://nasional.tempo.co/read/news/2016/02/09/078743187/diusir-bupati-bangka-9jemaat-ahmadiyah-masih-bertahan, Pada Tanggal 16 Maret 2017, Pukul 23:59 WIB.

15 Sukarno," A speech at the University of Indonesia, in Herbert Feith and Lance Castles eds., Indonesian Political Thinking 1945-1965, pp. 168-69.

16 Members of the Ahmadiyah, an Islamic religious movement deemed heretical by Indonesia's Sunni majority, have faced increased hostility in recent weeks, with a number of local communities being targeted across Java. It's become very difficult for Ahmadiyah communities in Indonesia to follow through on their religious beliefs, especially as violence and intimidation continue against them. They're victims of intolerant acts from communities that do not approve of their existence here in Indonesia. As hardline extremists groups like the Islamic Defender's Front (FPI) and the Islamic People's Front (FUI) have become more vocal, persecution against Ahmadis has increased in recent years.A quarterly report issued by the National Commission on Human Rights (Komnas HAM), which looked at religious freedom for the April to June period this year, noted multiple incidents of discrimination against Ahmadiyah groups, specifically in Bukit Duri 
Apakah sebuah kepercayaan menjadi sebab penganayaian terhadap orang atau golongan yang memeluknya? Bukankah setiap orang bebas memeluk agama dan beribadat menurut agamanya, memilih pendidikan dan pengajaran, pekerjaan, kewarganegaraan, memilih tempat tinggal di wilayah negara Indonesia? Bukankah setiap orang berhak atas kebebasan meyakini kepercayaan, menyatakan pikiran dan sikap, sesuai dengan hati nuraninya?18

Secara tidak kita sadari, kita telah melakukan tindakan yang menghilangkan hak asasi mereka yang berlabel Ahmadiyah. Bahkan kita sampai pada bentuk tindakan kekerasan dan diskriminasi. Seolah-olah mereka kita anggap sebagai 'enemy'. Padahal mereka punyak hak yang tidak boleh kita negasikan. Sadarkah kita bahwa sebenarnya apa yang kita lakukan juga bertentangan dengan prinsip-prinsip ajaran Islam. Hal ini sebagaimana tergambar dalam (Q.S 4:153) yang menyatakan bahwa:

"Orang-orang yang beriman kepada Allah dan para rasul-rasul-Nya dan tidak membeda-bedakan seorang pun diantara mereka, kelak Allah akan memberikan kepada mereka pahalanya."

Dari uraian yang sudah penulis kemukakan, tulisan ini akan mencoba untuk mengkaji lebih komprehensif terkait posisi kelompok Ahmadiyah sebagai 'minority' yang seharusnya menjadi objek perlindungan negara. Penulis juga mencoba menguraikan diskursus kebebasan beragama dengan mengkaitkannya dengan nilai-nilai dasar Islam. Perspektif objektif Islam menyikapi konflik yang dihadapi oleh Ahmadiyah.

\section{Metode Penelitian}

Metode penelitian ini menggunakan metode deskriptif. Metode penelitian ini digunakan untuk mencari unsur-unsur, ciri-ciri, sifat-sifat suatu fenomena. Metode ini mulai dengan mengumpulkan data, menganalis data dan menginterprestasikannya. ${ }^{19}$ Metode deskriptif ini dalam pelaksanaannya dilakukan melalui studi kritis konflik Ahmadiyah dengan menganalisis

and Depok. Information from the Association of Religion Data Archives indicates that there are an estimated 400,000 Ahmadi Muslims in Indonesia, with some communities dating as far back as the 1920s. 17 Jakarta Globe, "For Ahmadiyah in Indonesia, Persecution Remains Unaddressed", diakses
dari http://jakartaglobe.id/news/persecution-of-ahmadi-muslims-in-indonesia-remains-
unaddressed/, Pada Tanggal 17 Maret 2017 Pukul 19:00 WIB.
18 Pasal 28E ayat (1) dan (2) UUD 1945 menyatakan bahwa setiap orang bebas memeluk
agama dan beribadat menurut agamanya, memilih pendidikan dan pengajaran, memilih pekerjaan,
memilih kewarganegaraan, memilih tempat tinggal di wilayah negara dan meninggalkannya, serta
berhak kembali dan setiap orang berhak atas kebebasan meyakini kepercayaan, menyatakan
pikiran dan sikap, sesuai dengan hati nuraninya.
19 Suryana, "Metode Penelitian: Model Praktis Penelitian Kuantitatif dan
Kualitatif"(Bandung: Universitas Pendidikan Indonesia, 2010), h..20. 
perspektif hukum dan HAM yang disandingkan dengan nilai-nilai dasar keislaman.

\section{Pembahasan}

\section{Islam dan Perdamaian}

Islam beartikan tunduk atau menyerahkan diri dengan penuh kesadaran kepada Allah SWT. Manusia yang meninggalkan egonya, kebebasannya, dan menyerahkan diri sepenuhnya kepada Allah SWT. In all matters of life he obeys God's commandments. He begins to lead a restrained life instead of a permissive one. This is what is called Islam. ${ }^{20}$

Selain itu, dalam al-Qur'an Allah SWT berfirman (QS. 8 : 61)

“Dan jika mereka condong kepada perdamaian, maka condonglah

kepadanya dan bertawakkallah kepada Allah. Sesungguhnya

Dialah Yang Maha Mendengar lagi Maha Mengetahui."

Islam yang salah satunya berasal dari kata 'salm' dalam ayat di atas memiliki arti damai atau perdamaian. ${ }^{21}$ Dan ini merupakan salah satu makna dan ciri dari Islam, yaitu bahwa Islam merupakan agama yang senantiasa membawa umat manusia pada perdamaian. ${ }^{22}$

Interprestasi kata salam juga tampak pada pernyataan dibawah ini: "The word "Salam" means "Peace" and is derived from the same Arabic threeletter root SLM as the word Islam. "Salam" is one of the Attributes of Allah, blessed be His Names and Attributes and Exalted His Majesty" 23

Kata 'Salam' juga salah satu dari nama 'Jannah' (Paradise). ${ }^{24}$ Allah SWT berfirman:

"Bagi mereka (disediakan) Darussalam (surga) pada sisi Rabb-nya, dan Dialah Pelindung mereka, disebabkan amal-amal shaleh yang selalu mereka kerjakan." - (QS.6:127)

Penghuni surga akan saling menyapa dengan salam ketika mereka bertemu dengan Tuhan mereka sebagaimana dijelaskan bahwa:

\footnotetext{
${ }^{20}$ Maulana Wahiduddin Khan, "Islam and Peace", (India: Centre for Peace and Spirituality International, 2013), p.24.

21 The word Islam means submission to Allah the Almighty, the Creator and Lord of all creation, with the entire soul and body, by obedience to what He commanded and prohibited in His Revealed Law, by compliance and willful yielding of one's will to His Will and Judgments, and by acceptance of all that Allah has predestined for man on earth. Allah is the Most Beneficent and Merciful who knows all man's rightful needs, who enjoins all that is good and warns against all that is evil. Thus His revealed Law is perfectly suited to the universal needs, rights and responsibilities of man.

22 Dunia Islam, "Pengertian Islam Menurut Bahasa dan Istilah Dalam Al Quran", diakses dari http://www.duniaislam.org/23/03/2015/pengertian-islam-menurut-bahasa-dan-istilahdalam-al-quran/, Pada Tanggal 19 Maret 2017 Pukul 07:08 WIB.

${ }^{23}$ Abdur-Rahman Abdul Kareem Al-Sheha, "Islam is The Religion of Peace", (Saudi Arabia: islamland, 2015), p.10.

24 Abdur-Rahman Abdul Kareem Al-Sheha, Op.Cit., p.11.
} 
"Dan apakah mereka tidak berjalan di muka bumi, lalu melihat bagaimana kesudahan, orang-orang yang sebelum mereka, sedangkan orang-orang itu adalah lebih besar kekuatannya dari mereka. Dan tiada sesuatupun yang dapat melemahkan Allah, baik di langit maupun di bumi. Sesungguhnya Allah Maha Mengetahui, lagi Maha Kuasa." (QS.35:44)

Di bumi, ketika saling muslim bertemu mereka akan mengucapkan "As Salamu Alaikum" (Peace be upon you) dan ketika mereka berpisah pun mereka akan mengucapkan "As Salamu Alaikum" kembali. Bahkan ketika muslim memasuki rumahnya dan bertemu satu sama lain di sana, They said, "As-Salamu Alaikum since he offers this greeting upon the angels who are present in that place and upon himself".

Ucapan tersebut cenderung mempengaruhi (greeting helps) hati dari semua bentuk kejahatan, dendam dari orang-orang yang mungkin akan mencelakai kita. Semua bentuk kejahatan tersebut kemudian tergantikan (teredam) dengan niat yang baik, saling menghormati, ketenangan, keamanan dan kebahagiaan.

Perdamaian dalam Islam juga didukung berbagai prinsip fundamental. Salah prinsip fundamental dalam islam adalah tauhid. Tauhid adalah "prinsip kesatuan" yang merupakan lahan subur bagi spiritualitas dan keimanan Islam. Karena dengan Prinsip "kesatuan" Islam menganggap penting pluralitas, harmoni, toleransi, dan interrelasi, sebagai nilai-nilai fundamental, perdamaian antar manusia. Prinsip "kesatuan" juga menegaskan bahwa kehidupan manusia begitu sacral dan harus dirawat oleh semua manusia. ${ }^{25}$

Komitmen perdamain dan antikekerasan merupakan tujuan luhur yang harus dimanifestasikan dalam perkembangan pradaban Islam. ${ }^{26}$ Bahkan dalam dakwah Rasulullah menyebarkan agama Islam dengan jalan damai. Kemutlakan Islam ini harus diterima bagi umat Islam. Namun masalah iman, kembali pada subjektifitas manusia. Subjektifitas manusia menjadi hak mutlak manusia yang jika dikaitkan dengan 'dosa' itu urusannya dengan yang Maha Kuasa. Dalam konteks seperti ini bisa kita kaitkan dalam hal urusan 'iman' yang kemudian berkembang menuju 'kepercayaan dan keyakinan' bahkan bisa sampai tingkatan agama. Oleh karenanya, nilai-nilai fundamental Islam yang mengajarkan umat Islam cinta damai, mengharuskan umat Islam terhadap siapapun (termasuk Ahmadiyah) mendamaikan diri terhadap sesama. Seharusnya konflik itu tidak ada. Tidak ada pandangan sentimental. Cacian dan makian, sikap

25 Tita Rostitawati, Op.Cit, p.153.,

26 Nasaruddin Umar, "Deradikalisasi Pemahaman Al-Quran dan Hadis", (Jakarta: Rahmat Semesta Center, 2008), p. 201. 
usir-mengusir. Bukankah itu hak bagi mereka yang meyakini bahwa apa yang mereka lakukan itu sebuah kebenaran? Apakah yang kita lakukan merupakan upaya penyadaran terhadap mereka yang kita anggap sebuah kesesatan? Bukankah itu adalah hak subjektifitas mereka? Dan memang jika kesesatan pun apakah harus dilakukan dengan tindakan kekerasan? Bukankah tadi kita berpegang pada nilai-nilai fundamental dalam diri kita? Nilai-nilai fundamental Islam yang mengimani kita seharusnya menjadi integral dengan diri kita sendiri bukan malah hanya terjerat dalam pedoman hidup kita saja.

2. Islam: Ideologi Pergerakan Perdamaian dan Posisi Ahmadiyah dalam Lingkaran Perdamaian Islam

Jumlah muslim semakin meningkat di seluruh dunia. Meningkatnya jumlah Muslim disebabkan banyaknya Muslim yang mencari kesempatan berekonomi melalui upaya yang keras atas nama Islam. Orang-orang cenderung mengkonversikan dirinya layaknya Muslim. Orang-orang berpergian sebagai pedagang dan sambil membawa pesan Islam. Islam pun kemudian tersebar dengan berbagai cara damai (the way of peace). ${ }^{27}$ Cara damai ini kemudian being a dawa explosion in this world. 28

Dakwah tidak harus dipahami sebagai penyebaran Islam dengan cara berdagang, bargaining dan sebagainya. Ketika kita bepergian di toko-toko membeli atribut Islam, membeli Al-Quran dan Hadist (dengan menanyakan, "Ini tinggal berapa lagi jumlah Al-Quran dan Hadist?) dan sebagainya. Dengan kita menanyakan hal tersebut, sebenarnya juga sedikit menggentarkan hati orang lain yang mendengarnya. Masih banyak lagi. Kita juga menggemborkan melalui media masa, media sosial dengan berbagai aktivitas Islam. Intinya kesemua itu ditempuh melalui jalan damai. Ledakan dakwah dengan cara tersebut menunjukan bahwa Islam sebagai idelogi pergerakan yang cinta damai.

Ideologi perdamaian dalam Islam seharusnya tidak hanya sebatas ideologi saja.29 Apakah sebagai Muslim boleh memandang kelompok Ahmadiyah sebagai sebagai 'pihak lain' sehingga mengakibatkan dikotomi antara kita dan mereka? Bahkan dikotomi ini kemudian berkembang menjadi tindakan kekerasan secara fisik. ${ }^{30}$ Mengapa demikian? Karena

\footnotetext{
27 Sagaf S. Pettalongi, 2013, “Islam dan Pendidikan Humanis dalam Resolusi Konflik Sosial”, Jurnal Cakrawala Pendidikan, Th. XXXII, No. 2, p.174

${ }^{28}$ Maulana Wahiduddin Khan, Op.Cit., p. 233.

29 Moh. Toriqul Chaer, 2016, “ Islam dan Pendidikan Cinta Damai”, ISTAWA: Jurnal Pendidikan Islam, Vo. 2, No. 1, p. 78.

30 Therefore, according to the Quran, we do not have the right to call anyone kafir which is the situation that emerges when the Muslims see non-Muslims as the 'other.' To call people kafir just because they do not claim to be Muslim is to violate God's injunctions. Menyebut non-muslim kafir saja sebenarnya dilarang oleh Al-Quran dan Hadist. Apalagi membenci kelompok yang
} 
pengakuan secara sosial dalam koridor majority of Islam Ahmadiyah tidak mendapat posisi atau kedudukan. Walaupun secara hukum Ahmadiyah. Hal inilah mengakibatkan anarkisme oknum-oknum Islam muncul dengan berbagai sikap ekstrim. Kemudian Penulis mulai bertanya. Apakah mereka yang menurut kita menyimpang dari prinsip-prinsip Islam itu harus mengatur kembali jarak antara kita dan mereka? Bahkan kita menjadikan mereka sebagai musuh. Kenapa kita tidak mencoba suatu upaya yang lebih revolusioner. Misalnya menjadikan musuh sebagai teman (an enemy is to be treated as a friend. One should consider even one's enemy as a potential friend and respond to his mistreatment with goodness). Menurut Penulis, pandangan yang seperti ini kemudian melahiran a closer distance atau bahkan tidak jarak antara kita dan mereka, tidak penilaian baik dan buruk, malaikat dan iblis. Sehingga kemudian perlahan kita mulai menerima eksistensi Ahmadiyah. Memang ini bukan suatu perkara yang mudah. Bicara soal paradigma memang membutuhkan waktu yang rentan lama. Apalagi jika doktrin itu sudah kita anggap sebagai dogmatis. Belum lagi oknum-oknum yang memanaskan keadaan-keadaan menjadi lebih buruk.

Situasi-situasi seperti ini yang harus kita sadari dan refleksikan kembali bahwa ada apa dengan diri kita? Sadarkah kita bahwa sebenarnya kita ini mudah sekali terprovokasi? Terprovokasi dengan berbagai kecurigaan-kecurigaan yang ujung-ujungnya negative thinking atau persangka buruk yang terealisasikan dengan sikap anarkis di akhirnya. ${ }^{31}$ Barangkali memang kita tidak menyadari ini. Kemudian ketaksadaran kita itu, berdampak pada kelompok lain yang menjadi objek tindakan atas ketaksadaran kita. Kita yang tidak mengakui posisi Ahmadiyah secara sosiologis (majority of Islam), apakah kita sudah mendalami nilai-nilai fundamental Islam yang terdapat dalam Al-Quran dan Hadist? Apakah kita sudah berintegrasi dengan prinsip-prinsip dasar Islam? Pantaskah kita sebagai Muslim yang menaggap Ahmadiyah sesat lalu kita usir mereka dengan cara-cara kekerasan? Kemudian kita sebut diri kita Muslim yang benar dan bermartabat? Bukankah setiap orang berhak atas kebebasan meyakini kepercayaan, menyatakan pikiran dan sikap, sesuai dengan hati nuraninya? Komentar penulis, kita ini negara Islam atau negara hukum?32

sebenarnya 'include' one of sect's Islam ditambah lagi sampai pada bentuk kekerasan. Hal ini sangat jauh dari prinsip-prinisp fundamental Islam.

31 Moh. Rosyid, 2013, "Resolusi Konflik Berlatar Agama: Studi Kasus Ahmadiyah di Kudus", Jurnal Multikultural dan Multireligius, Vol 12. No. 3 p. 53.

32 Berbicara soal konsep negara itu tidak ada habisnya. Ada yang mengatakan Indonesia negara hukum, negara Islam karena mayoritas penduduk Indonesia adalah muslim. Ada juga yang mengatakan negara Pancasila, sosialis pancasila, negara Islam Nusantara dan masih banyak. Di atas penulis sodorkan dua opsi karena mengingat konteks diksi kalimatnya. 
Terkait dengan hak kebebasan agama dan keyakinan akan penulis jelaskan lebih lanjut.

\section{Posisi Ahmadiyah sebagai Kelompok Minoritas}

Jika suatu kelompok minoritas yang tidak memiliki kekuasaan dan hanya meninginkan pengakuan serta kebebasan tentu akan tergirus, terkucilkan bahkan mendapatkan tindakan kekerasan jika secara eksistensinya saja kelompok minoritas tersebut tidak mendapatkan legitimasi secara hukum dan sosial. Posisi Ahmadiyah sebagai kelompok minoritas patut untuk kita perihatinkan. Padahal Ahmadiyah sudah mengalami proses nasionalisme yang berkembang di seputar isu kultural sebelum 1920-an hingga muncul ide tentang kemerdekaan dengan semangat kebangsaan melawan kolonialisme dan imperialisme Belanda serta Barat. ${ }^{33}$

Polemik eksistensi Ahmadiyah mulai tampak ketika Indonesia diambil alih oleh Jepang. Mengapa? Karena Jepang menganggap Ahmadiyah merupakan antek Inggris. ${ }^{34}$ Pergolakan tersebut terus berlarut hingga sekarang. Padahal pasca kemerdekaan Indonesia, Ahmadiyah resmi memiliki badan hukum sebagai bukti bahwa Ahmadiyah sebagai organisasi yang sah dan diakui oleh pemerintah.

Pergolakan Ahmadiyah muncul berbagai tempat di Indonesia. Paling sering mendapatkan penolakan dan kekerasan ialah Ahmadiyah Qodian atau dikenal sebagai Jamaah Ahmadiyah Indonesia (JAI). Angka tertinggi atas penolakan dan kekerasan terhadap Ahmadiyah terjadi di Jawa Barat sebagai pusat JAI dan juga beberapa daerah lain. ${ }^{35}$ Berbeda dengan JAI, Ahmadiyah Lahore justru aman di Yogyakarta. ${ }^{36}$ Meskipun juga kadang mendapatkan penolakan dan kekerasan dari masyarakat. Konflik yang dihadapi Ahmadiyah Lahore di Yogyakarta cenderung konflik horizontal saja. Namun proteksi dari Gubernur Yogyakarta justru menjamin lansung keamanan warga Ahmadiyah. Di Yogyakarta Ahmadiyah bahkan sudah memiliki sekolah yang di sebut sekolah Persatuan Islam Seluruh Indonesia (PIRI), sehingga Jamaah Ahmdiyah Lahore yang berpusat di Yogyakarta jarang terdengar ketika kekerasan dan penolakan terjadi terhadap Jamaah Ahmadiyah.

33 Iskandar Zulkarnain, Gerakan Ahmadiyah di Indonesia (Yogyakarta: LKiS, 2005), p. 12.

34 Ibid.

35 Sigit Purnomo, "Nasib Ahmadiyah, terlantar di negeri sendiri", diakses dari http://www.bbc.com/indonesia/berita_indonesia/2013/08/130802_ahmadiyah_lombok, Pada Tanggal 21 Maret 2017 Pukul 20:06 WIB.

36Indro, "Sultan Jamin Ahmadiyah di Yogyakarta", diakses dari http:/ / m.news.viva.co.id/cangkang/ramadan2014/read/203384-sultan-jamin-ahmadiyah-diyogyakarta-aman, Pada Tanggal 21 Maret 2013, Pukul 20:13 WIB. 
Ahmadiyah Qodian di Jawa Barat, Surabaya, Lombok, dan di beberapa kota lain, sudah terbiasa dengan penolakan dan kekerasan, bahkan pengusiran seperti yang terjadi di Lombok Barat. Menurut Setara Institute antara tahun 2007-2009 terjadi pelanggaran terhadap Jamaah Ahmadiyah sebanyak 286 pelanggaran, sama sekali. ${ }^{37}$ Tidak ada jaminan keamanan dari pemerintah secara langsung seperti halnya dengan Ahmadiyah Lahore di Yogyakarta.

Persoalan Ahmadiyah sebenarnya sudah terjadi tahun 1950-an. Namun legitimasi bahwa Ahmadiyah menyimpang terjadi tahun 1980-an sejak MUI mengeluarkan fatwa di tahun 1984 bahwa Ahmadiyah menyimpang dari prinsip-prinsip Islam. ${ }^{38}$ Tahun 2005 MUI mengeluarkan fatwa kembali dengan menguatkan fatwa tahun 1984 bahwa Ahmadiyah sesat dan pemerintah diwajibkan untuk melarang penyebaran ajaran Ahmadiyah. ${ }^{39}$ Puncak dari penolakan tersebut terjadi pada tahun 2008 dengan dikeluarkan Surat Keputusan Bersama Tiga Menteri (SKB). Rangakain larangan yang dikeluarkan oleh beberapa pemerintah daerah juga turut mempengaruhi kekerasan terhadap Jamaah Ahmadiyah, eskalasi kekerasan di beberapa daerah semakin meningkat setiap tahun. Catatan Setara Institute, pelanggaran terhadap Ahmadiyah pada tahun 2007 sebanyak 15 pelanggaran, 193 pelanggaran pada tahun 2008, 33 pelanggaran pada tahun 2009, dan 50 pelanggaran pada tahun 2010. Antara tahun 2007, 2009, dan 2010 pelanggaran terus mengalamai peningkatan, sedangkan tahun 2008 merupakan jumlah terbanyak dari jumlah pelanggaran terhadap Ahmadiyah, tahun di mana tepat SKB tiga menteri dikeluarkan. ${ }^{40}$ Tidak hanya itu, sebelum tahun 2001, selain fatwa MUI, larangan juga dikeluarkan oleh Kepala Kejaksaan Negeri Selong, Lombok Timur dengan no Kep. 11/IPK.32.2/L2.III.3/11/83 tahun 1983 tentang pelarangan terhadap kegiatan Jamaah Ahmadiyah Cabang Pancor, Lombok Timur. ${ }^{41}$ Pelarangan tersebut tiga tahun setelah dikeluarkan fatwa MUI tentang Ahmadiyah.

37 Setara Institute, Atas Nama Ketertiban dan Keamanan (Jakarta: Setara Institute, 2010).

38 Majelis Ulama Indonesia Bidang Aqidah dan Aliran Keagamaan, Ahmadiyah Qodian (Jakarta: MUI, 1980).

39 Majelis Ulama Indonesia Bidang Aqidah dan Aliran Keagamaan, Penjelasan Tentang Fatwa Aliran Ahmadiyah (Jakarta: MUI, 2005).

40 Kementrian Agama Republik Indonesia, “SKB Ahmadiyah, Pemerintah Pertimbangkan Perkembangan Situasi", diakses dari https://www2.kemenag.go.id/berita/79849/skb-ahmadiyahpemerintah-pertimbangkan-perkembangan-situasi?lang=id, Pada Tanggal 21 Maret 2017 Pukul 21.22 WIB.

41 Yudhasmara, "Pelarangan Ahmadiyah Meluas Dimana-mana", diakses dari https:/ / www.google.com/search?q=kejakaan+keluarkan+surat+larangan+ahmadiyah\&ie=utf8\&oe=utf-8\&client=firefox-b, Pada Tanggal 21 Maret 2017, Pukul 21:48 WIB. 
Kondisi kebebasan beragama di Indonesia dalam satu dekade terakhir memang cukup memperihatinkan, pengerusakan tempat ibadah, kekerasan terhadap penganut Ahmadiyah serta diskriminasi yang dilakukan oleh masyarakat semakin marak. Ruang gerak Ahmadiyah dalam menjalankan keyakinan dipersempit, tidak hanya masyarakat menjadi pelaku langsung kekerasan terhadap Ahmadiyah, namun juga dilakukan oleh pemerintah daerah yang melegitimasi kekerasan yang dilakukan oleh masyarakat dengan peraturan-peraturan daerah yang diskriminatif.42 Hal tersebut merupakan bukti nyata bahwa sebagai kelompok minoritas yang tidak mendapatkan pengakuan secara hukum dan sosial sudah pasti cenderug mendapatkan kekerasan baik dilakukan oleh sentimental horizontal masyarakat maupun vertikal pemerintah. Lalu bagaimana dengan hak kebebasan beragama? Lebih lanjut penulis akan menjelaskan Ahmadiyah diskursus kebebasan beragama dan kebebasan keyakinan.

4. Ahmadiyah: Hak Kebebasan Beragama dan Berkeyakinan (Proteksi Negara terhadap Eksistensi Ahmadiyah)

Sejak pergantian rezim pemerintahan di tahun 1998, Indonesia sudah mereformasi legislasi nasional untuk lebih menyesuaikan prinsip-prinsip HAM internasional dengan memperkenal undang-undang baru, amandemen konstitusi dan ratifikasi perjanjian HAM internasional. Namun, perjuangan terhadap kelompok Ahmadiyah yang sedang berlansung menggambarkan bahwa tidak tercapainya kesepakatan pada beberapa prinsip dasar HAM, yaitu hak kebebasan beragama. ${ }^{43}$ Di satu sisi, kasus Ahmadiyah menunjukan bagaimana kedua organisasi beragama memanfaatkan ruang publik yang mencoba mempengaruhi pemerintah. Di sisi lain, hal itu menunjukan bahwa pemerintah Indonesia masih ragu-ragu untuk melepaskan kontrol negara atas agama. Tanpa kita sadari, bahwa kasus Ahmadiyah ini didorong oleh tuntutan sekte muslim yang radikal dan menolak permintaan dari pendukung kebebasan beragama. Hal ini tampak jelas dalam deskripsi di bawah ini:

The first, in July 2005, culminated with a fatwa by the Indonesian Ulama Council (MUI) demanding the government to ban Ahmadiyya. The second gathered momentum from late 2007, reaching its peak in early June 2008 when a joint ministerial decree was released concerning Ahmadiyya and its teachings. 44

42 Abdul Gaffar, 2013, “Jamaah Ahmadiyah Indonesia (JAI) Dalam Perspektif Kekerasan Negara: Dua Kasus Dari Surabaya Jawa Timur dan Lombok NTB”, Jurnal Sosiologi Islam, Vol. 3, No.2, p. 31.

43 Leena Anvonius, 2008, "The Ahmadiyah \& freedom of religion in Indonesia", ISIM Review 22; Society and The State, p. 48.

${ }^{44}$ Leena Anvonius, Op.Cit., p. 47. 
Walaupun sebenarnya pergolakan Ahmadiyah muncul jauh kebelakang sejak era pergantian rezim 1988, namun puncaknya terjadi di tahun 2005 dan 2008. Tahun 2005 MUI mengeluarkan fatwa dengan mengkuatkan kembali fatwa yang dikeluarkan Tahun 1984 (isinya meminta Pemerintah untuk menghentikan segala aktivitas Ahmadiyah) dan di tahun 2008 dikeluarkannya SKB. Dalam kedua situasi ini, ketegangan yang dibangun oleh organisasi Islam radikal melalui lobi, pertemuan yang cenderung isinya hasut-menghasut dan kekerasan yang dilakukan oleh Islam radikal tersebut bertujuan untuk menjadikan Ahmadiyah sebagai suatu masalah dimana Pemerintah dan MUI harus mencari solusi atas masalah tersebut. Jadi pertemuan yang dilakukan oleh organisasi Islam yang radikal tersebut malah cendrung memprovokasi MUI dan institusi Pemerintah bukan untuk menarik akar persoalan apakah Ahmadiyah merupakan permasalahan atau bukan? Hasil lobi politik ini kemudian menghasilkan Bakorpakem (Badan Koordinasi Pengawasan Aliran dan Kepercayaan) yang berfungi untuk mengawasi isu intoleransi. ${ }^{45}$

Bakorpakem melarang segala bentuk kegiatan Ahmadiyah. Apabila pelarangan itu bertujuan untuk melindungi keamanan (dalam arti keamanan pribadi pemeluk agama) atau melindungi ketertiban (dalam arti menjamin berfungsinya masyarakat), maka tindakan yang diambil Bakorpakem untuk melarang segala bentuk kegiatan aliran Ahmadiyah sulit untuk dibenarkan. Sebab perlindungan tidak identik dengan pelarangan, apalagi yang didahului dengan kekerasan. Faktanya, penganut aliran Ahmadiyah yang terancam dan merekalah yang harus dilindungi. Hal ini sebenarnya membuktikan bahwa kebebasan beragama di Indonesia masih dibatasi. Apabila kebebasan beragama dibatasi berdasarkan hukum nilai moral masyarakat, nilai yang merupakan dasar pembatasan harus diambil lebih dari satu tradisi/kebiasaan, bukan hanya berdasarkan pandangan arus utama. ${ }^{46}$ Dengan demikian, pembatasan tidak boleh didasarkan pada fatwa MUI saja, walaupun Presiden Susilo Bambang Yudhoyono dalam Rapat Kerja Nasional MUI November 2007 menyatakan bahwa dalam menangani isu aliran sesat, pemerintah memohon fatwa MUI sebagai landasan bagi aparat negara untuk bertindak, dan walaupun Jaksa Agung Muda Intelijen, Wisnu Subroto yang juga wakil ketua Bakorpakem, mengakui bahwa Bakorpakem selalu mengundang saksi ahli dan lembagalembaga agama yang diakui negara, seperti MUI, KWI, PGI, Walubi,

\footnotetext{
45 Muhammad Zulfikar, "Pemerintah Bentuk Bakorpakem Tangani Isu Intoleransi", diakses http://www.tribunnews.com/nasional/2014/01/22/pemerintah-bentuk-bakorpakemtangani-isu-intoleransi, Pada Tanggal 22 Maret 2017, Pukul 18:26 WIB.

46Brigham Young University, "Kebebasan Beragama atau Berkeyakinan", (Yogyakarta: Kanisius, 2010), p. 700.
} 
Parisada Hindu Dharma Indonesia, dan Matakin karena Bakorpakem dianggap tidak mempunyai kompetensi dalam menilai teologi. Tafsir agama ini menjadi rujukan badan dalam menilai kemurnian suatu aliran kepercayaan, dan dalam menilai apakah kebebasan eksternal dari kebebasan ini sesuai dengan nilai moral masyarakat.

Hak atas kebebasan beragama adalah prinsip yang mendukung kebebasan individu atau masyarakat, dalam ruang publik maupun pribadi untuk memanifestasikan agama atau kepercayaan dalam pengajaran, praktek, ibadah serta ketaatan. Konsep ini juga mencakup kebebasan untuk berpindah agama atau untuk tidak mengikuti agama apapun. Kebebasan beragama jauh dari intoleransi dan diskriminasi yang mengacu pada segala bentuk pembedaan, pengecualian, pembatasan atau prefensi atas dasar agama atau keyakinan yang berakibat pada pembatalan atau berkurangnya pelaksanaan hak-hak dasar yang berdasarkan asas kesetaraan. Setara Institute membedakan antara intoleransi aktif dan intoleransi pasif. Intoleransi pasif adalah residu dari keyakinan seseorang bahwa agamanya adalah satu-satunya agama yang benar. Kondisi demikian mengharuskan individu tersebut untuk menerima perbedaan, karena konteks ketidakterimaan ia adalah tidak tepat, yakni ketika ia sedang berada dalam lingkaran interaksi sosial. Di sisi lain, intoleransi aktif bukan hanya meyakini bahwa agamanya adalah satu-satunya agama yang benar, tetapi juga memiliki kecenderungan untuk melihat mereka yang berbeda agama atau bahkan yang berbeda interpretasi dalam agama yang sama sebagai sesat dan menyimpang. Sebuah perbedaan nyata antara dua bentuk intoleransi terletak pada bagaimana seseorang berperilaku dan bertindak. Mereka yang berada dalam kategori intoleransi aktif tidak hanya mengungkapkannya secara lisan tetapi juga melalui tindakan. ${ }^{47}$

Berbicara mengenai hak kebebasan beragama tentu kita harus merujuk pada UUD 1945 terkhusus pada Pasal 28E yang mengatur tentang Hak Kebebasan Beragama dan Berkeyakinan.48 Pasal 28E UUD 1945 memberikan jaminan bagi setiap orang untuk bebas memeluk agama/keyakinan dan atau kepercayaannya. Ketentuan tersebut implisit mendeklarasikan kebebasan bagi siapa saja untuk beragama/berkeyakinan. Pada saat bersamaan, jaminan kebebasan

47 Tim Peneliti, “Kebebasan Beragama di Indonesia 2010 - 2012", (Jakarta Selatan: INFID, 2013) p. 12.

48 Mengapa demikian? Karena Indonesia sebagai negara hukum yang didalamnya terhadap pengakuan atas jaminan perlindungan HAM. Hak kebebasan beragama dan kebebasan berkeyakinan merupakan bagian dari HAM yang harus mendapatkan proteksi dari negara. Terlebih lagi rujuan UUD 1945 sebagai konstitusi negara terdapat uraian otentik yuridis terkait hak kebebasan beragama dan berkeyakinan di Indonesia. 
beragama juga diiringi dengan jaminan bagi setiap orang untuk beribadah menurut agama yang diyakininya itu.

Adanya jaminan dalam UUD 1945 menunjukkan bahwa hak beragama atau pemelukan suatu agama oleh seseorang merupakan hal yang esensial dalam hak asasi manusia. Dalam bahasa yang lebih tegas, Seto Harianto mengatakan bahwa hak beragama itu adalah hak yang paling asasi dari semua hak asasi manusia. ${ }^{49}$ Lebih lanjut dalam pembahasan tentang materi hak beragama bukan pemberian negara, bukan pemberian golongan, karena itu negara tidak bisa mewajibkan warganya atau bahkan negara tidak boleh ikut campur terhadap persoalan agama warga negaranya masing-masing. ${ }^{50}$ Bahkan dalam Islam, prinsip saling menghormati antarpara pemeluk agama yang berbeda sangat ditekankan. Hal ini sesuai dengan firman Allah SWT, lakum dienukum waliyadin. "Berpegang teguhlah engkau pada agamamu dan aku berpegang pada agamaku." (QS. Al-Kafirun, ayat 6). Toleransi dalam beragama merupakan salah satu dasar ajaran Islam. ${ }^{51}$ Dengan kata lain, prinsip keyakinan setiap manusia terhadap Tuhannya tidak boleh dipaksakan karena bertentangan dengan nilai-nilai Islam. ${ }^{52} \mathrm{Hal}$ ini tampak jelas dalam Firman Allah SWT:

“Tidak boleh ada paksaan dalam Agama. Sungguh telah nyata (berbeda) kebenaran dan kesesatan. Karena itu, barang siapa yang ingkar kepada thaghut (Syaitan) dan beriman kepada Allah, sesungguhnya ia telah berpegang kepada tali yang amat kuat yang tak akan putus. Allah Maha Mendengar dan Maha Mengetahui." (QS. AlBaqarah: 256).

Prinsip utama hak dasar kemanusiaan dalam Islam terdapat beberapa aspek yang perlu diperhatikan agar kemashlahatan umat bisa terwujud. Imam Ghazali (w.1111 M), mengembangkan prinsip kemanusiaan Islam, yang kemudian terkenal dengan sebutan Ushul alKhamsah (lima dasar), yang kemudian dielaborasi lebih luas oleh Abu Ishaq al-Syathibi dalam kitabnya Al-Muwafaqat fi Ushul al-Syari'ah. Salah satu di antaranya adalah perlindungan agama (hifz al-din). ${ }^{53}$

49 Reformata, "Tabloid Reformata Edisi 54 Februari Minggu II 2007", (Bandung: Yapama, 2007), p.23.

50 Sigit Riono. 2015 “Hak Kebebasan Beragama di Indonesia (Studi Socio-Legal dalam Kasus Ahmadiyah)". Skripsi. Program Fakultas Hukum Universitas Negeri Semarang, Semarang, p. 73.

51 Harun Nasution dan Bahtiar Effendy, "Hak Asasi Manusia dalam Islam", (Jakarta: Yayasan Obor Indonesia, 1987), p. xi.

52 Syaefullah. 2014. "Civil Society dan Kebebasan Beragama di Indonesia: Studi Kasus The Wahidinstitute". Skripsi. Program Fakultas Hukum Universitas Islam Negeri Syarif Hidayatullah, Jakarta, p. 26.

53 Bisri Effendy, dkk, "Modul Pendidikan Islam dan Hak Asasi Manusia", (Jakarta: ELSAM, 2010), p. 20 
Perlindungan terhadap agama ini kemudian ditafsirkan sama dengan kebebasan dalam memeluk agama. Islam secara tegas mengatakan bahwa tidak ada paksaan dalam memeluk agama, bahkan setiap manusia diberikan pilihan yang bebas untuk beriman atau tidak. Namun dalam kenyataannya jangankan keluar dari Islam, berbeda mazhab dalam Islam saja, oknum Islam kemudian melakukan tindakan yang menegasikan hak bagi penganut aliran tersebut. Seperti hal penganut Ahmadiyah tidak mendapatkan ruang kebebasan di Indonesia. Padahal mereka memiliki hak kebebasan beragama dan berkeyakinan yang semua itu harus dihormati, dilindungi dan dipenuhi oleh negara. Penghormatan terhadap hak kebebasan beragama dan berkeyakinan Ahmadiyah bearti negara tidak boleh melanggar HAM mereka. Pemerintah tidak boleh menahan diri dari menghalangi dinikmatinya hak dan kebebasan Ahmadiyah. Pemerintah tidak boleh menutup akses kelompok Ahmadiyah terhadap akses pelayanan publik. Selanjutnya negara harus melindungi Ahamdiyah. Misalnya ketika kelompok Ahmadiyah akan melakukan sholat berjemaah di masjid, melakukan kegiatan-kegiatan keagaaman dan sebagainya negara wajib melindunginya. Karena Ahmadiyah termasuk dalam warga negara Indonesia dan mereka semua merupakan objek dari perlindungan negara sesuai dengan amanah konstitusi. Pemerintah tidak boleh mengintervensi hak atas keyakinan beragama, dan beribadat seseorang. Tafsir penting lainnya ialah negara tidak boleh menentukan suatu agama atau keyakinan sebagai "resmi" atau "benar", sementara yang lain "sesat" atau "menyimpang". Dalam konteks kewajiban ini polisi tidak boleh menghambat hak beribadat seseorang termasuk hak beribadat kelompok Ahmadiyah. Perlindungan dan pemenuhan hak kebebasan beragama dan berkeyakinan Ahmadiyah ini dilakukan melalui instrumen kebijakan pemerintah, baik itu kebijakan hukum, sosial, politik dan budaya. Kebijakan hukum berupa produk hukum yang telah dibuat dan menegasikan hak Ahmadiyah harus dicabutkan serta menciptkan produk hukum yang tidak mensyaratkan SARA, tidak diskriminasi dan harus berbasiskan HAM. Kemudian negara juga dapat bekerjasama dengan lembaga-lembaga yang bergerak di bidang pengarusutamaan HAM misalnya seperti Komnas HAM, Komnas Perlindungan anak dan Perempuan, Ombudsman untuk membuat laporan terhadap situasi Ahmadiyah. Pemerintah harus mampu mengelola keberagaman agama di Indonesia melalui mengkomunikasikan organisasi agama besar seperti halnya Muhammadiyah sebagai pihak yang menyelesaikan sengketa dan mendorong inisiatif lokal terhadap isu intoleransi agama. Negara harus menyediakan suatu mekanisme koreksi bila hak atas berkeyakinan, beragama dan beribadah seseorang dilanggar, termasuk di dalamnya 
menyediakan suatu saluran dimana seseorang bisa mengajukan keluhan jika merasa haknya tersebut dilanggar. Negara harus membuat suatu jaminan hukum yang mengakui dan mengatur hak berkeyakinan, beragama, dan beribadat. Negara harus membantu atau memberikan perhatian khusus (affirmative action) kepada kelompok-kelompok rentan (minoritas agama termasuk Ahmadiyah) untuk bisa memenuhi hak-hak atas berkeyakinan, beragama dan beribadah mereka. ${ }^{54}$

Dengan kedudukan yang demikian, maka hak beragama pun ditempatkan sebagai non-derogable rights sebagaimana dinyatakan Pasal 28I ayat (1) UUD 1945. Sebagai hak yang terkategori non-derogable rights, maka hak beragama/berkeyakinan tidak dapat dikurangi dalam keadaan apapun atau tidak dapat dicabut oleh siapapun.

Selain memberikan jaminan dan kedudukan sebagai non derogable rights terhadap hak beragama/berkeyakinan, UUD 1945 juga mengatur hubungan negara dan agama serta kedudukan atau posisi negara dalam konteks penghormatan dan perlindungan hak tersebut. Hal ini tergambar dalam Pasal 29 UUD 1945 yang menyatakan bahwa:

Negara berdasarkan atas Ketuhanan Yang Maha Esa dan Negara menjamin kemerdekaan tiap-tiap penduduk untuk memeluk agamanya dan kepercayaannya itu..$^{55}$

Sesuai ketentuan Pasal 29 UUD 1945, negara mengemban tanggung jawab konstitusional untuk melindungi hak beragama setiap warga negara. Negara memiliki kewajiban untuk menjamin kebebasan beragama/berkeyakinan sebagaimana dinyatakan dalam Pasal 28E dan Pasal 29 UUD 1945. Hal itu sejalan dengan mandat Pasal 28I ayat (4) UUD 1945 yang harus dipenuhi negara, terutama pemerintah. Pasal 28I ayat (4) menyatakan bahwa:

Perlindungan, pemajuan, penegakkan, dan pemenuhan hak asasi manusia adalah tanggung jawab negara, terutama pemerintah.

Itu berarti bahwa pemerintah dibebani kewajiban untuk melindungi dan menghormati hak asasi manusia. Kewajiban pemerintah untuk melindungi (to protect), memajukan (to promote), memenuhi (to fulfill) dan menghormati (to respect) terhadap nilai-nilai hak asasi manusia sebagaimana diamanatkan Pasal 28 I ayat (4) UUD 1945. Di sini negara tidak terlibat dalam memberikan "fatwa" apakah suatu ajaran agama benar atau salah. Secara konstitusional negara tidak boleh mendiskriminasikan agama dan kepercayaan warganya. Tugas negara adalah memberikan perlindungan, pelayanan, dan membantu warga untuk membangun serta

54 Tim Penulis, "Panduan Pemolisian dan Hak Berkeyakinan, Beragama dan Beribadah", (Jakarta: Kontras, 2012) p. 27.

55 Pasal 29 Undang-Undang Dasar Republik Indonesia Tahun 1945. 
memelihara saranan peribadatan, agar warganya menjadi pemeluk agama yang baik. Bahkan hal ini dipertegaskan kembali dalam Putusan MK No. 140/PUU-VII/2009 terkait UU No. 1/PNPS/1965 bahwa dalam pertimbangannya MK menyatakan pengakuan seluruh agama dan kepercayaan secara konstitusional tanpa ada bentuk diskriminasi. Hal ini menunjukan bahwa hak kebebasan beragama dan berkeyakinan adalah hak yang fundamental. Oleh sebab itu, kewajiban untuk memberikan jaminan, perlindungan, pemajuan hak asasi manusia, khusus hak beragama bagi setiap warga negara ada pada negara. Kewajiban negara untuk melindungi HAM setiap individu di bawah juridiksi kuasanya menyakut dua hal: upaya negara mencegah terjadinya terjadinya suatu pelanggaran HAM oleh pihak manapun, bila terjadi suatu pelanggaran HAM negara harus melakukan koreksi. Contohnya dengan melakukan investigasi, penuntutan, dan penghukuman bagi pelakunya dan memulihkan hak-hak si korban (atau keluarganya). Kewajiban untuk melindungi ini memiliki aspek horizontal karena negara juga wajib mengatur tata relas antar aktor-aktor non negara. Selanjutnya kewajiban Pemerintah untuk memenuhi hak Ahmadiyah. Kewajiban pemerintah untuk menekankan pada upaya-upaya positif negara lewat mekanisme legislatif, yudikatif atau administratif untuk menjami implementasi HAM termasuk hak kebebasan beragama dan berkeyakinan Ahamdiyah di tingkat yang paling konkret bisa dinikmati oleh kelompok Ahmadiyah di bidang juridiksi kuasanya.

\section{Simpulan dan Saran}

\section{Simpulan}

Konflik merupakan keniscayaan sejarah dan berpeluang muncul. Makna positif konflik berupa terjadinya perubahan sosial, makna negatif berupa kerenggangan sosial dan kekerasan. Memahami konflik bearti juga harus mengetahui sebab munculnya konflik. Penyebab konflik Ahmadiyah disebabkan oleh rekonsiliasi konflik dengan kompromi. Rekonsiliasi konflik adalah tindakan konstruktif yang diagendakan, dilakukan dan dievaluasi oleh para pihak dengan tujuan untuk menyelesaikan konflik. Tindakan konstruktif tersebut sangat ditentukan kesediaan menggapai perdamaian dengan prinsip saling menyadari dan memahami, tanpa merasa dirugikan. Tentunya upaya mencapai perdamaian tersebut harus menggunakan prinsip-prinsip dasar Islam sebagai resolusi konflik Ahmadiyah.

Toleransi, keadilan dan tindakan saling memaafkan harus dipahami dan direfleksikan serta harus menjadi integral dengan sikap bermasyarakat. Mengingat prinsip-prinsip tersebut merupakan nilai dasar 
Islam maka sudah seharusnya sebagai muslim harus meneladani tiga prinsip tersebut. Jika prinsip tersebut dipahami dan diteladani maka pemahaman terhadap hak kebebasan beragama akan mudah pahami sehingga sikap lansung menerima kebijakan dengan argumentum ad populum atau argumentasi yang diberikan oleh pihak yang berwenang lansung dianggap sebagai kebenaran tanpa mengkritisi kebijakan tersebut. Pemahaman terhadap hak kebebasan beragama sebagai non-derogable rights yang dijamin oleh UUD 1945 seharusnya menjadikan negara tidak ikut campur dalam hal urusan agama dan berkeyakinan. Karena hak untuk beragama dan berkeyakinan diserahkan secara mutlak kepada individu. Kebijakan pelarangan segala kegiatan Ahmadiyah menurut Penulis tidak dapat dibenarkan. Sebab perlindungan tidak identik dengan pelarangan, apalagi yang didahului dengan kekerasan. Malahan seharusnya eksistensi Ahmadiyah yang kedudukannya terancam dan harus mendapat perlindungan oleh negara. Apabila kebebasan beragama dibatasi berdasarkan hukum nilai moral masyarakat, nilai yang merupakan dasar pembatasan harus diambil lebih dari satu tradisi/kebiasaan, bukan hanya berdasarkan pandangan arus utama.

\section{Saran}

a. Hak-hak kebebasan beragama dan berkeyakinan dijamin dalam UUD 1945. Sementara pemerintah telah mengeluarkan kebijakan-kebijakan yang bersifat diskriminatif mencakup SKB Tiga Menteri Tahun 2008 tentang Ahmadiyah, Peraturan Bersama Dua Menteri Tahun 2006 tentang Pendirian Tumah Ibadah, dan UU No. 1/PNPS/1965 tentang Penodaan Agama. Termasuk berbagai peraturan daerah tentang pembatasan kegiatan Ahmadiyah. Kebijakan-kebijakan pemerintahan yang diskriminatif merupakan bentuk negasi dari hak-hak kebebasan beragama dan berkeyakinan yang dijamin dalam UUD 1945. Oleh karena itu, pemerintah harus memandang serius dan bersikap integral dengan UUD 1945 sebagai norma dasar negara (norma yang melandasi pelaksanaan kebijakan negara).

b. Pemerintah harus mampu mengelola keberagaman yang ada di Indonesia. Perangkat pemerintah seperti aparat kepolisian, gubernur, bupati/walikota perlu mendapatkan pemahaman tentang HAM, dalam kaitannya dengan isu yang diangkat dalam tulisan ini, maka pemerintah harus lebih memahami dan mewujudkan hak kebebasan beragama dan berkeyakinan.

c. Pihak Kementerian Agama harus netral dan imparsialitas terhadap salah satu pemahaman keagamaan. Kementerian ini harus mendorong organisasi keagamaan (misalnya Muhammadiyah dan Nahdlatul Ulama sebagai organisasi Islam terbesar di Indonesia) dalam menyelesaikan 
sengketa dan mendorong inisiatif lokal untuk menangani masalahmasalah yang terkait dengan intoleransi beragama.

d. Melibatkan seluruh komisi negara yang ada, termasuk Komnas HAM, Komnas Perempuan, Komisi Perlindungan Anak Indoensia dan Ombudsman untuk membuat laporan independen tahunan tentang situasi kebebasan beragama di Indonesia.

e. Negara harus membuat suatu jaminan hukum yang mengakui dan mengatur hak berkeyakinan, beragama, dan beribadat. Negara harus membantu atau memberikan perhatian khusus (affirmative action) kepada kelompok-kelompok rentan (minoritas agama termasuk Ahmadiyah) untuk bisa memenuhi hak-hak atas berkeyakinan, beragama dan beribadah mereka

\section{Referensi}

Jurnal

Anvonius, Leena. 2008. "The Ahmadiyah \& freedom of religion in Indonesia". ISIM Review 22; Society and The State.

Chaer, Moh. Toriqul. 2016. "Islam dan Pendidikan Cinta Damai". ISTAWA: Jurnal Pendidikan Islam, Vo. 2, No. 1.

Gaffar, Abdul. 2013. "Jamaah Ahmadiyah Indonesia (JAI) Dalam Perspektif Kekerasan Negara: Dua Kasus Dari Surabaya Jawa Timur dan Lombok NTB". Jurnal Sosiologi Islam. Vol. 3, No.2.

Hussein, Sawsan Malla. 2014. "The Concept of Peace in Islam". International Journal of English Language. Vol. III, Issue VIII.

Rosyid, Moh. 2013. "Resolusi Konflik Berlatar Agama: Studi Kasus Ahmadiyah di Kudus". Jurnal Multikultural dan Multireligius.Vol 12. No. 3.

Sukarno. 2000. "A speech at the University of Indonesia, in Herbert Feith and Lance Castles eds". Journal of Indonesian Political Thinking 1945-1965.

Tita Rostitawati, Tita. 2014 "Teologi dalam Islam". Jurnal Madani. Vol 4. No 1.

Pettalongi, Sagaf S. 2013. "Islam dan Pendidikan Humanis dalam Resolusi Konflik Sosial". Jurnal Cakrawala Pendidikan. Th. XXXII, No. 2.

\section{Buku}

Al-Sheha, Abdur-Rahman Abdul Kareem. 2015. "Islam is The Religion of Peace". Saudi Arabia: islamland.

Brigham Young University. 2010. "Kebebasan Beragama atau Berkeyakinan". Yogyakarta: Kanisius.

Khan, Maulana Wahiduddin. 2013. "Islam and Peace". India: Centre for Peace and Spirituality International.

Majelis Ulama Indonesia. 1980. "Bidang Aqidah dan Aliran Keagamaan, Ahmadiyah Qodian". Jakarta: MUI.

Indonesia. 2005. "Bidang Aqidah dan Aliran Keagamaan, Penjelasan Tentang Fatwa Aliran Ahmadiyah". Jakarta: MUI.

Nasution, Harun dan Bahtiar Effendy. 1987. "Hak Asasi Manusia dalam Islam". Jakarta: Yayasan Obor Indonesia. 
Reformata. 2007. "Tabloid Reformata Edisi 54 Februari Minggu II 2007". Bandung: Yapama.

Setara Institue. 2010. “Atas Nama Ketertiban dan Keamanan”. Jakarta: Setara Institute.

Suryana. 2010. "Metode Penelitian: Model Praktis Penelitian Kuantitatif dan Kualitatif". Bandung: Universitas Pendidikan Indonesia.

Tim Peneliti. 2013. "Kebebasan Beragama di Indonesia 2010 - 2012". Jakarta Selatan: INFID.

Umar, Nasaruddin. 2008. "Deradikalisasi Pemahaman Al-Quran dan Hadis". Jakarta: Rahmat Semesta Center.

Zulkarnain, Iskandar. 2005. "Gerakan Ahmadiyah di Indonesia". Yogyakarta: LkiS.

\section{Skripsi}

Sigit Riono. 2015 "Hak Kebebasan Beragama di Indonesia (Studi Socio-Legal dalam Kasus Ahmadiyah)". Skripsi. Program Fakultas Hukum Universitas Negeri Semarang, Semarang.

Syaefullah. 2014. "Civil Society dan Kebebasan Beragama di Indonesia: Studi Kasus The Wahidinstitute". Skripsi. Program Fakultas Hukum Universitas Islam Negeri Syarif Hidayatullah, Jakarta.

\section{Internet}

Dunia Islam. Pengertian Islam Menurut Bahasa dan Istilah Dalam Al Quran. http:/ / www.duniaislam.org/23/03/2015/pengertian-islam-menurutbahasa-dan-istilah-dalam-al-quran/ diakses tanggal 19 Maret 2017.

Florentin, Vindry 2017. Ahmadiyah Minta Pemerintah Penuhi Hak-Haknya. https://nasional.tempo.co/read/news/2016/02/09/078743212/ahmadiya h-minta-pemerintah-penuhi-hak-warga-negaranya diakses tanggal 16 Maret 2017.

Florentin, Vindry. 2017. Diusir Bupati Bangka, 9 Jemaat Ahmadiyah Masih Bertahan.

https://nasional.tempo.co/read/news/2016/02/09/078743187/diusir-

bupati-bangka-9-jemaat-ahmadiyah-masih-bertahan diakses tanggal 16 Maret 2017.

Hamdi, Imam. 2017. Masjid Disegel, Ahmadiyah Depok Tempuh Jalur Hukum. https://metro.tempo.co/read/news/2017/02/24/083850004/masjiddisegel-ahmadiyah-depok-tempuh-jalur-hukum diakses tanggal 16 Maret 2017.

Idhom, Addi Mawahibun. 2017. Menteri Agama Sesalkan Perusakan Masjid Ahmadiyah.

https://nasional.tempo.co/read/news/2016/05/24/173773523/menteriagama-sesalkan-perusakan-masjid-ahmadiyah diakses tanggal 16 Maret 2017.

Indro. Sultan Jamin Ahmadiyah di Yogyakarta. http://m.news.viva.co.id/cangkang/ramadan2014/read/203384-sultanjamin-ahmadiyah-di-yogyakarta-aman diakses tanggal 21 Maret 2013. 
Jakarta Globe. 2017. For Ahmadiyah in Indonesia, Persecution Remains Unaddressed. http://jakartaglobe.id/news/persecution-of-ahmadimuslims-in-indonesia-remains-unaddressed/. diakses tanggal 17 Maret 2017.

Kementrian Agama Republik Indonesia. SKB Ahmadiyah, Pemerintah Pertimbangkan Perkembangan Situasi. https://www2.kemenag.go.id/berita/79849/skb-ahmadiyah-pemerintahpertimbangkan-perkembangan-situasi?lang=id diakses tanggal 21 Maret 2017.

Purnomo, Sigit. Nasib Ahmadiyah, terlantar di negeri sendiri. http://www.bbc.com/indonesia/berita_indonesia/2013/08/130802_ahma diyah_lombok, diakses tanggal 21 Maret 2017.

Yudhasmara. Pelarangan Ahmadiyah Meluas Dimana-mana. https:/ / www.google.com/search?q=kejakaan+keluarkan+surat+larangan + ahmadiyah\&ie=utf-8\&oe=utf-8\&client=firefox-b diakses tanggal 21 Maret 2017.

Zulfikar, Muhammad. Pemerintah Bentuk Bakorpakem Tangani Isu Intoleransi. http://www.tribunnews.com/nasional/2014/01/22/pemerintah-bentukbakorpakem-tangani-isu-intoleransi diakses tanggal 22 Maret 2017.

\section{Peraturan Perundang-Undangan}

Undang-Undang Dasar Republik Indonesia 1945.

Undang-Undang Nomor 39 Tahun 1999 tentang Hak Asasi Manusia. 